\title{
Does Giving the Learner Control Improve Learner Success?
}

\author{
Abdu Al Nashrey ${ }^{1, *}$ \\ ${ }^{1}$ School of Education, Communication and Language Sciences, Newcastle University, UK \\ *Corresponding author: School of Education, Communication and Language Sciences, \\ Newcastle University, UK. E-mail: a.a.a.al-nashrey3@ncl.ac.uk
}

Received: August 6, 2020 Accepted: August 21, 2020 Published: September 25, 2020

doi:10.5296/ije.v12i3.17492ＵRL: https://doi.org/10.5296/ije.v12i3.17492

\begin{abstract}
This research aims to determine the most suitable style of educational control over the use of multimedia by high school chemistry students in Saudi Arabia. The research aims to quantify the effect of styles of educational control over multimedia (program or learner control) on 16-17 year old students' achievements in chemistry. The sample consists of two groups of 30 students. The first group studied with the learner control style while the second studied using the program control style. The results show that the improvement in chemistry test scores in the first group was better than in the second, with a statistically significant difference between groups at the $\alpha=0.05$ level. As a result of this research we recommend, firstly, using the learner control style when designing multimedia programs because of its demonstrated positive effect on achievement; and, secondly, expanding the use of educational programs for individual learning to other areas of education. In summary, this research highlights the beneficial combination of multimedia technology and pedagogy.
\end{abstract}

Keywords: control patterns, multimedia software, program control, learner control 


\section{Introduction}

\subsection{Introduce the Study}

The Saudi Arabian educational system supports an international curriculum and the Ministry of Education has recently improved the secondary school system with the introduction of a new program in so-called Tatweer Schools. These new schools have an innovative system that includes advanced technological equipment and allows students the flexibility to choose subjects and teachers for each semester, as well as offering them the possibility of studying during the summer. With regard to secondary schooling, there are two types, private and government schools, with the majority of students attending the latter as they are free to do so. As part of the Kingdom of Saudi Arabia's Vision 2030 (2017) scheme, which sets out national transformation goals, there are aims concerned with learning and with developing current and future generations, including providing citizens with learning resources that allow the quality and outcomes of learning to be improved.

The impact of scientific and technological progress is clear in many areas of life, including education, and this has placed on the shoulders of educators the need to keep up with this new technology. The entry of technologies into the field of education has become a necessity rather than a luxury. It is fair to say that the beginning of progress of any nation and its prosperity depends heavily on the development of education.

Multimedia playback is the most important multimedia application. Many studies have been conducted on multimedia computer programs in the acquisition and development of skills and cognitive experience (Kingsley \& Boone, 2008). Multimedia programs help to develop opportunities for self-learning as they enable the learners to control what they learn in a way that suits them. The two educational control methods are known as learner control and program control.

However, the studies that have examined the impact of multimedia on learning outcomes have not addressed some of the main variables in the production of multimedia programs themselves, most notably with regard to learning control styles. In learner control, the learner has power over the educational situation through their control of the sequence of content, the pace of learning, and the amount of practice and feedback. In contrast, program control is based on the idea of guiding the learner through a program whose paths are pre-determined, and thus the learner does not have the opportunity to change the method of learning or the material sequencing (Wang \& Beasley, 2002).

Starting from this shortcoming, this current study deepens our understanding of multimedia program control. Previous studies have disagreed over which method of control was more effective, a problem which we aim to address in the forthcoming text.

\subsection{Rationale for the Study}

Working as a chemistry teacher, the researcher noted that student achievement was low, and determined to explore methods to address this.

The researcher conducted many interviews with chemistry teachers in separate schools in 
Alqunfudhah governorate to find which part of the first secondary grade chemistry course they found most difficult; with all respondents in agreement that the third semester was the hardest part of the course, a fact confirmed by the final exam results.

The researcher also noted that most of the previous studies that were concerned with multimedia and its use in educational computer programs had not addressed one of the most important variables in the production of educational computer programs, namely educational control, despite the potentially strong benefit this variable offers.

The question now is, not whether to use the computer in education, but what are the most appropriate employment strategies in the educational process. Therefore, the production of educational computer programs must develop to reach a distinct level of quality.

Many observations have shown that secondary school teachers often use unsuitable teaching techniques. Through conducting sporadic interviews, it was found that many students believe that their teachers lacked the necessary skills to deliver suitable classes to learners. Interviews of teaching staff highlighted that many lack the necessary technical skills to allow them to use modern technology in their pedagogy. Furthermore, many teachers believed that technology took up too much time in the classroom.

In turn, this leads to consideration of multimedia computer program design, focusing on the educational control method as an important variable in exploring the effect of the difference in educational control patterns within multimedia programs: is it better for the learner to control the software or for the program to control itself, and what is the impact of that choice on students' achievement in chemistry?

\subsection{Study Hypothesis}

There are no statistically significant differences at the level $(\alpha=0.05)$ between the mean scores in the post-application achievement test of students in the first experimental group, who used the software with learner control, and those of the second experimental group, who used the software with program control.

\subsection{Aims of the Study}

The present study aims to achieve the following:

- Identify the effect of the educational control patterns of multimedia programs on achievement;

- Determine the most appropriate types of educational control patterns for high school students.

\subsection{Importance of the Study:}

It is hoped that this study will be useful in the following ways:

- Helping educators, educational supervisors and curriculum planners to identify how best to employ multimedia in teaching chemistry;

- Reducing the difficulties of teaching chemistry to first-grade secondary students by 
presenting an interesting computer program that presents the subject matter in a positive and attractive manner;

- Guiding future preparation of multimedia computer programs in order to increase students' achievement in other courses;

- Determining the most appropriate method of educational control in building educational software and thereby increasing the effectiveness of these programs;

- Identifying the most age-appropriate educational control method in multimedia software for first-year high school students.

\section{Education in Saudi Arabia}

According to the Saudi Arabian Ministry of Education (2019), the current education system in the country began in 1926, when the first school was established in Makah. There is currently significant investment in education with the aim of delivering further improvements. Alongside King Abdullah's project for improving public school education, government funding has also been allocated to a new mathematics and science curriculum. As mentioned previously, Tatweer schools have been developed, the name deriving from the national company that has been appointed to drive these changes. Tatweer provides professional development programs for both science supervisors and teachers to enable them to teach using new materials. As a result of these changes, science education in Saudi Arabia is now the subject of increasing attention.

The first step in achieving the government's vision is to improve the curriculum, which takes a comprehensive perspective and comprises students and teachers, school and home, strategies and society. A curriculum is defined as the learning material for a particular stage of education, and includes elements that the student may find in their textbooks, including concepts, definitions, theories, facts, laws, values, trends, and skills. In secondary school, science consists of several separate subjects, biology, chemistry, computer science, geology and physics; while the curriculum has four main components: aims, content, teaching methods and evaluation (Alhomairi, 2018). The science curriculum essentially aims to teach and prepare students with scientific knowledge, allowing them to think effectively about the scientific phenomena that they will encounter in society. Chemistry is a dependent subject in secondary school and so only qualified teachers are employed to teach it.

\section{Literature Review}

Multimedia software refers to any combination of text, image, video, graphics and animation to create knowledge accessed by multiple senses, such as sight and hearing. Beauchamp et al. (2005) identified multimedia as the digital presentation of information, which can incorporate text, audio, and still and moving images. Regarding the use of multimedia software, three kinds are available depending on whether control is maintained by the learner, the program or is 
flexible. Hooper et al. (1993) defined learner control to mean giving learners the right to make educational decisions, so that additional assistance can be requested, changes made to the level of difficulty and quantity of training, and control can be exercised over the sequence of content according to the needs of the individual. On the other hand, program control entails one educational sequence for all students, regardless of their interests or needs, whereas flexible control modifies the characteristics of the lesson according to the students' preparation, their tribal levels, and their learning needs. Naidu (1995) identified the program control strategy as having a linear direction, and being non-branching as a result, because it works according to the program's orders. That is, the program controls the learning time, the sequence of content, the amount of training imposed on the learner, and the provision of information, all by moving within the program in a manner prescribed by the program without learner intervention.

In discussing multimedia program control, many concepts and phrases can be considered synonymous, such as Adaptive Control, Linear Control, Absolute Control, Free Access and Limited Access.

Many studies have shown that multimedia methods have a positive effect on students' achievement at all ages because it brings together text, sound and imagery. For example, Alarishi (2009) found a statistically significant difference in students' average test scores in science between a control group that studied in a traditional fashion and an experimental group that studied using multimedia. In addition, Zard (2010) examined the effectiveness of proposed educational software on achievement in a biology course by using two experimental groups of approximately 21 students each, one of which was taught using educational software, and the other taught in a traditional manner. The study found statistically significant differences at the 0.05 level between the average scores of students on a post-achievement test between the experimental and control groups, in favor of the experimental group. After controlling for the pre-achievement scores, these differences occurred at three cognitive levels: remembering, understanding, and application. In this study, the use of multimedia software enhanced learning is at the basic levels in Bloom's taxonomy, namely remembering, understanding and applying.

To build on this concept, a self-organized learning environment (SOLE) gives students the opportunity and flexibility to build their learning at any time and without restriction. Mitra et al. (2010) saw that SOLE could encourage teachers to let their students answer questions by working as a community with both the assistance of computers and internet access.

On the other hand, many studies have claimed that program control in multimedia learning works better than learner control. Eom \& Reiser (2000), for instance, examined the effects of learners' use of the self-organizing strategy on their achievement and motivation in computer-based learning. The study sample consisted of 30 sixth-grade students who were divided into two groups who were then taught using either learner or program control. The results showed that learners using program control scored higher in the post-test than learners using learner control, and that performance was weaker in learners with low self-control. No differences in motivation were found between the two groups.

Yeh \& Lehman (2001) indicated that students being in control showed a greater summons compared to those using program control, and this indicates that the environment that the 
learner controls is better than the environment that the program controls in the learning of English.

Program control occurs where the program is the primary controller in the learning time, in the sequence of content, and of how many examples are imposed on the learner, and in providing feedback and therapeutic frameworks for the learner, all of which is presented in a fixed linear path. Al-Ayafi \& Hamid (2019) found a statistically significant difference at the 0.05 level, between the average test scores of students using a patterned electronics control (control) and students using a control made using electronics (non-controlling), in favor of non-controlling among students in an intermediate school in Saudi Arabia. In the same way, Silalahi et al. (2018) found that multimedia based on offline learning positively affected students' motivation and outcomes in chemistry.

However, other studies found no difference between the two styles of multimedia software. For example, Ibrahim (2012) found no statistically significant differences between the two methods (learner control and program control), either in a mathematical reasoning test or in an achievement motivation scale, among secondary age learners deemed to be slow learners of mathematics in Egypt. Similarly, Aly et al. (2005) found no statistically significant difference between a learner control group and program control group among undergraduate students of dentistry when they studied via computer assisted learning. Notwithstanding this, current guidance still requires a role model in inspiring pupils to learn, especially those who struggle with using multimedia to learn. Wang \& Beasley (2002) examined learner control in educational environments and learner control with guidance using 81 students from Taiwan University, who were divided into two groups. Their results indicated that the learner control method with advice is more beneficial than the learner control method alone, and also that the presence or absence of advice or guidance did not affect students who were highly skilled.

\section{Approach and Methodology}

\subsection{Approach}

Positivism is the paradigm followed in this study. It posits that there are universal laws and that the researcher can therefore be objective and neutral in investigating them (Thompson, 1995, pp. 62-72). Consequently, a quantitative quasi-experimental research method is most appropriate to the nature of the present study. Herein, the educational control pattern (learner control or program control) is the independent variable, while achievement in chemistry is the dependent variable. The first group in the experiment used educational software with a learner control pattern, while the second group used a program control pattern.

\subsection{Methodology}

Quantitative methodology was used to compare the students' achievements. The study variables consisted of independent and dependent variables. The independent variable had two levels of control pattern: learner control and program control. The dependent variable is students' achievement. 


\subsubsection{Study Sample}

The research population comprises all 2571 first grade students at the secondary stage in Alqunfudah city, described in the statistics for the Information and Computer Center in the Education Department in Alqunfudah. The study sample was intentionally chosen from first grade students in the secondary stage at King Abdullah bin Abdul Aziz School (Boys) in Alqunfudah City. 60 students were randomly divided into two groups: the first experimental group had 30 students, and were taught using educational software with a learner control mode. The second experimental group also had 30 students but were taught using educational software with a program control pattern. Table (1) shows the numbers in the study sample.

Table 1. Number of Students in Each Group

\begin{tabular}{ccc}
\hline Group & Number & Program \\
\hline 1 & 30 & learner control \\
2 & 30 & program control \\
\hline
\end{tabular}

The sample was limited to male students due to the Muslim faith in the Kingdom of Saudi Arabia, which demands gender segregation in school (excepting the first stage in primary school). Consequently, the current study was conducted in a boys' school and therefore, it applies to male students only.

\subsubsection{Study Procedures}

The researcher reviewed the following study tools and prepared them according to the order in which they were used in the study. First, a study unit comprising the third semester of the chemistry course was chosen for the first secondary class of the first semester. Titled Composition of the Atom, this was to be the scientific content under study.

Analysis of the educational content was carried out, and the educational objectives were defined. The scientific subject matter pertinent to achieving the program's educational goals was identified as the third chapter of the chemistry curriculum for the first secondary class, which is typically presented as a series of four lessons: definition of the atom; how do atoms differ, unstable nuclei; and radioactive decay.

These objectives were presented to a number of arbiters, to seek their views on the following:

* The extent of clarity of the educational goals;

* The extent of provision of scientific content to meet these educational goals.

Some objectives were modified or supplemented after arbitration. The most important of which amended the formulation of some educational goals, and added further goals, to several lessons. Consequently, the Bergman \& Moore (1990) model was used to generate content (see Fig.1). Content design began with two different scenarios for the two multimedia programs; the first allows students flexibility by providing control over the length of study time, while the other 
restricted the student's time, depending on the content viewed. The scenario was approved by two academic staff, before transference into both programs using Adobe Authorware software.

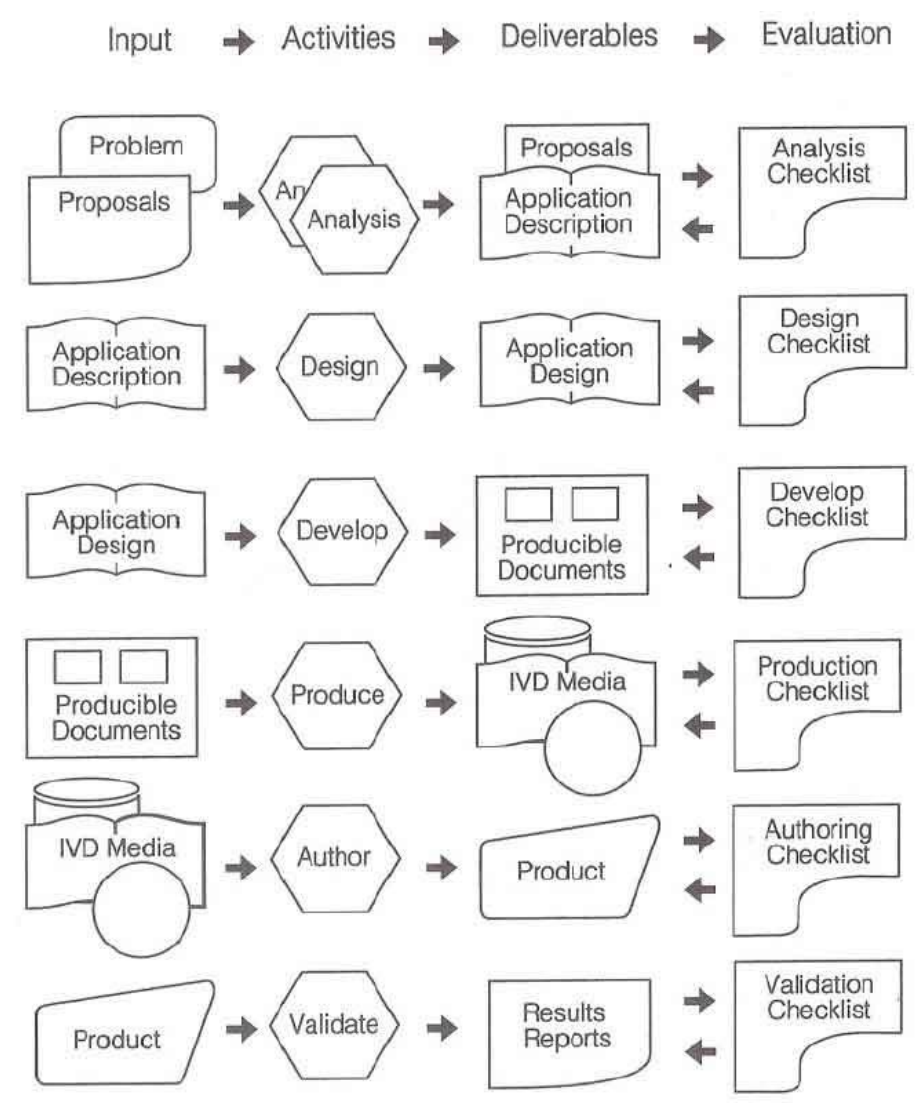

Figure 1. Bergman and Moore's 1990 Model (Bergman \& Moore, 1990)

The following steps were taken to build an achievement test: goal setting, building, pilot testing, and only then modification, and final construction. The preliminary knowledge gained after completion of post-arbitration modifications, allowed acceptance of the test as a valid research tool.

An exploratory sample of 20 students was chosen from the first secondary class of Hussein bin Ali School in Alqunfudhah City. The study tools (chemistry achievement test and the two programs with different patterns of control) were applied to this cohort, in order to ascertain the validity and reliability of the tests, to check the efficiency of the tools, and evaluate and avoid certain aspects during application.

\subsubsection{Limitations}

Key limitations arose from the design of the school, which had few electrical sockets available, with not more than three per classroom. To negate this, electrical connections were provided to allow all students to charge their laptop during class time. There was a limited maintenance service provision for student devices due to insufficient staffing. 


\section{Analysis}

SPSS was used for data analysis. The reliability of the achievement test was calculated by applying it to a survey sample from the same population, namely the 20 students from the first year of secondary school at Al-Hussein Bin Ali Secondary School in Alqunfudah City. Tool reliability was ascertained by calculating Chronbach's Alpha; with a value of $0.76(n=30)$ indicating a reliable test.

Table 2. Reliability Statistics

\begin{tabular}{cc}
\hline Cronbach's Alpha & N of Items \\
\hline .760 & 30 \\
\hline
\end{tabular}

Pre-intervention achievement test means of the two groups were calculated in order to ensure that the two groups were initially, approximately equal. The means were 10.6 and 11.5 for the program control and learner control groups respectively.

In computing group homogeneity through achievement test scores in the pre-measurement, it was found that there were no statistically significant differences between the two research groups at the 0.05 level, which indicates the homogeneity of the two groups before experimentation. Therefore, it can be considered that the two groups are equivalent before the experiment, and that any differences that appear after this are due to the effect of the independent variable, rather than pre-existing differences. After intervention for both two groups, post-test results were obtained. The t-test results are shown in Table 3.

Table 3. Independent Samples Test

\begin{tabular}{|c|c|c|c|c|c|c|c|c|c|}
\hline & \multicolumn{2}{|c|}{$\begin{array}{c}\text { Levene's Test } \\
\text { for Equality of } \\
\text { Variances }\end{array}$} & \multicolumn{7}{|c|}{ t-test for Equality of Means } \\
\hline & \multirow[t]{2}{*}{$\mathrm{F}$} & \multirow[t]{2}{*}{ Sig. } & \multirow[t]{2}{*}{$\mathrm{t}$} & \multirow{2}{*}{$\mathrm{df}$} & \multirow{2}{*}{$\begin{array}{c}\text { Sig. } \\
\text { (2-tailed } \\
\text { ) }\end{array}$} & \multirow{2}{*}{$\begin{array}{c}\text { Mean } \\
\text { Difference }\end{array}$} & \multirow[t]{2}{*}{$\begin{array}{l}\text { Std. Error } \\
\text { Difference }\end{array}$} & \multicolumn{2}{|c|}{$\begin{array}{c}95 \% \text { Confidence Interval } \\
\text { of the Difference }\end{array}$} \\
\hline & & & & & & & & Lower & Upper \\
\hline $\begin{array}{l}\text { Equal variances } \\
\text { assumed }\end{array}$ & .000 & .999 & 2.708 & 57 & .009 & 2.77701 & 1.02536 & .72377 & 4.83025 \\
\hline $\begin{array}{l}\text { Equal variances } \\
\text { not assumed }\end{array}$ & & & 2.7075 & 6.782 & .009 & 2.77701 & 1.02584 & .72263 & 4.83139 \\
\hline
\end{tabular}

In order to identify tool bias, bootstrap values were calculated as 0.009 , which signifies very low bias. Group normality was assessed using the Shapiro-Wilk statistic for the two groups, resulting in 0.125 for learner control and 0.365 for program control. With both groups' 
significance higher than 0.05 , indicative of a normal distribution of post-test scores.

Table 4. Tests of Normality

\begin{tabular}{lllll}
\hline & Group & \multicolumn{3}{c}{ Shapiro-Wilk } \\
\cline { 3 - 5 } & & Statistic & df & Sig. \\
\hline \multirow{2}{*}{ Students } & 1.00 & .945 & 30 & .125 \\
& 2.00 & .963 & 30 & .365 \\
\hline
\end{tabular}

\section{Results}

The study reached the following results:

- There are statistically significant differences, at the $\alpha=0.05$ level, between the average post-test achievement scores of students who were taught using software with learner control and those who were taught using program control, with the learner control group performing higher $(\mathrm{M}=21.46, \mathrm{Std}=3.88)$. For comparison, the median post-intervention score for the learner control group was $\sim 21$, while that of the program control group was $\sim 18$ (see chart 1 ).

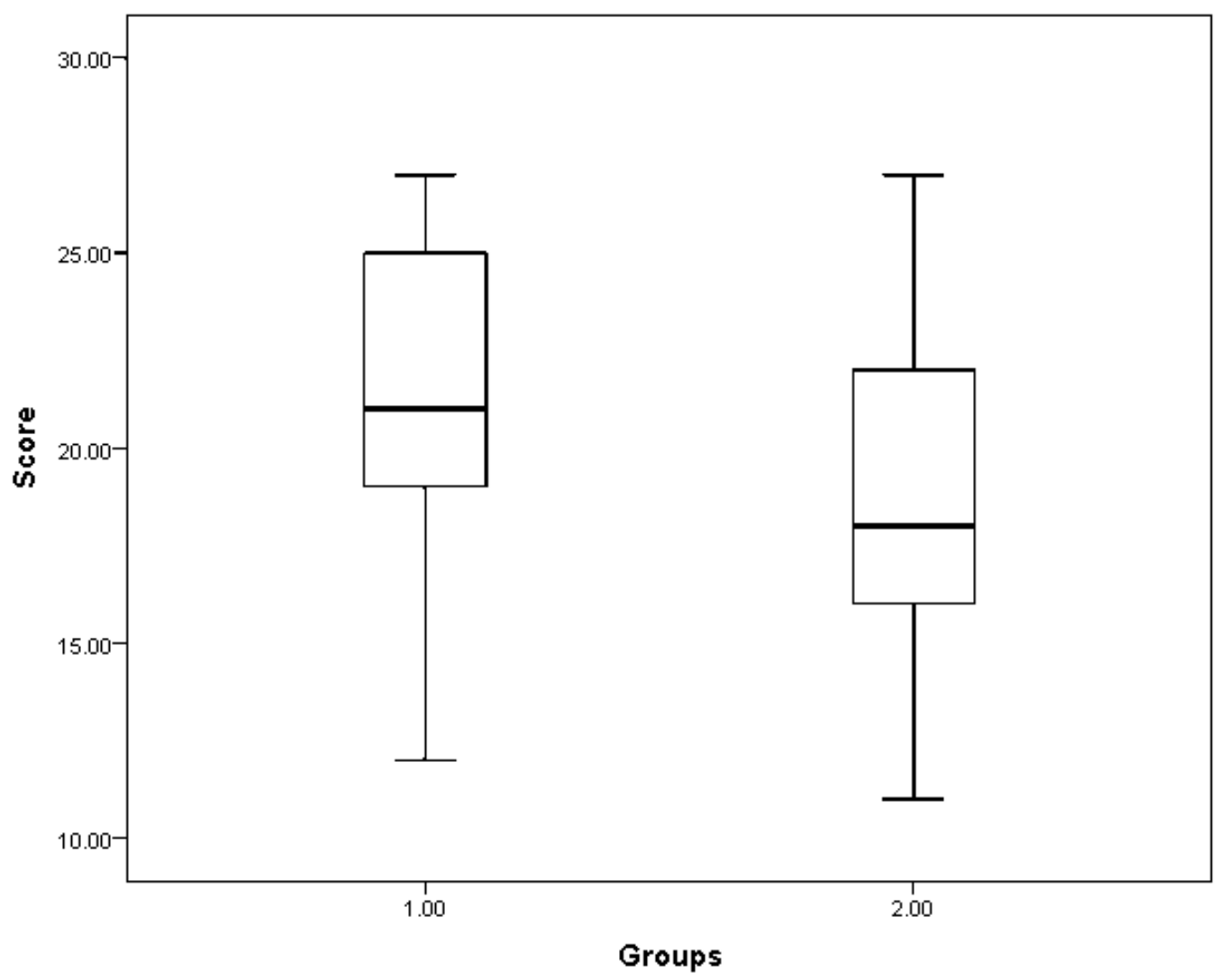

Chart 1. Post Intervention Scores of the Two Groups

Group 1: Learner Control; 2: Program Control 
- There are statistically significant differences at the level $(\alpha=0.05)$ between the mean scores of students taught with learner control software in the pre-test $(\mathrm{M}=11.5, \mathrm{Std}=4.06)$ and the post-test $(M=21.46, S t d=3.88)$ in favor of the post-test. This shows that their chemistry knowledge improved over the course of the intervention.

- There are statistically significant differences at the level $(\alpha=0.05)$ between the mean scores of students who were taught using program control software in the pre-test $(\mathrm{M}=10.6, \mathrm{Std}=3.77)$ and the post-test $(\mathrm{M}=18.6, \mathrm{Std}=3.93)$, skewed in favor of the post-test. This indicates that this group also improved their chemistry knowledge.

\section{Discussion}

Giving students the opportunity to control multimedia educational software is shown in this study, in agreement with Alarashī (2009), and Zard (2010), who investigated self-learning organization without time restriction. On the other hand, the results are contrary to those of Al-Ayafi \& Hamid (2019), who found that non-control was more effective than controlled multimedia for student achievement.

From the results gained, it is possible to suggest avenues for future research:

1) A study on the effect of the independent variable of the current research (learner control program control) on other educational outcomes, such as learning time or skills;

2) A study on the effect of the interaction between the independent variable of the current research (learner control - program control) and the cognitive style of students (impulsive metro) on immediate and delayed attainment;

3) A study of the effect of electronic books, split by type of control (learner control - program control), on student achievement and their motivation for this achievement;

4) A study on other types of software control such as (total control - partial control) and the effect of this on learning time and learning rate;

5) A study of patterns of programming control such as (learner control - learner control with guidance) and the impact of these on learning and performance rates;

6) A study on the impact of the independent variable of the current research (learner control program control) through high-media software on other educational outcomes such as learning time or skills.

\section{Conclusion}

Multimedia software enhances learning through multi-sensual stimulation. There are different ways of exercising control of multimedia software, depending on the user requirements. Two main educational control methods in multimedia programs were investigated: learner control and program control. According to the extant literature, studies may be divided into three 
categories: those that found that learner control is better than program control, those that found no difference, and those that found that program control to be more effective than learner control.

The present study found that, among students in the first stage of secondary school, aged 16-17 years, giving students control over their multimedia software assisted learning enabled them to achieve higher scores in chemistry than when having control exercised by the program itself. This result suggests further research to explore the relationship between the style of control in multimedia and other variables, such as time taken to learn and age of students, may be needed if this literary discrepancy is to be addressed.

\section{Acknowledgments}

The author appreciates support from the Saudi Arabian government, in particular the Ministry of Education for the opportunity to conduct research in the United Kingdom. Dr. Abduh Almuashi, Dr. Ibrahim Almarhbi, and Thamer Marzuoq are thanked for their assistance and advice. The author is particularly grateful to King Abdullah Secondary School in offering their site, equipment, students, and additional facilities required for the experimental work described herein.

\section{References}

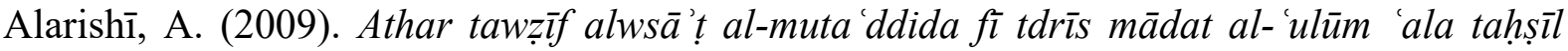
tlāmìdh al-șsaf al-sāis al-ibtidā i fì madinat Jazan. [The effect of employing multimedia in teaching science on the achievement of sixth grade pupils in Jizan city]. (Unpublished Master's dissertation). Umm Al Qura University, Saudi Arabia.

Al-Ayafi, K. M. A., \& Hamid, M. Z. A. (2019). The effect of interaction between the control pattern and the style of activities' guidance in the multimedia software on developing the skills of using internet with intermediate level students. Journal of Educational and Psychological Sciences, 3(14). https://doi.org/10.26389/AJSRP.K301218

Alhomairi, A. O. A. (2018). A proposed perspective for developing science curriculum for the upper primary grades in accordance to Saudi Arabia's Vision for 2030: An analytical and descriptive study according to Delphi Method. International Journal of Higher Education, 7(1), 69-86. https://doi.org/10.5430/ijhe.v7n1p69

Aly, M., Elen, J., \& Willems, G. (2005). Learner-control vs. program-control instructional multimedia: a comparison of two interactions when teaching principles of orthodontic appliances. European Journal of Dental Education, 9(4), 157-163. https://doi.org/10.1111/j.1600-0579.2005.00385.x

Beauchamp, N., Irvine, A. B., Seeley, J., \& Johnson, B. (2005). Worksite-based internet multimedia program for family caregivers of persons with dementia. The Gerontologist, 45(6), 793-801. https://doi.org/10.1093/geront/45.6.793 
Bergman, R. E., \& Moore, T. V. (1990). Managing interactive video/multimedia projects. Educational Technology Publications.

Eom, W., \& Reiser, R. A. (2000). The effects of self-regulation and instructional control on performance and motivation in computer-based instruction. International Journal of Instructional Media, 27(3), 246-261.

Hooper, S., Temiyakarn, C., \& Williams, M. D. (1993). The effects of cooperative learning and learner control on high-and average-ability students. Educational Technology Research and Development, 41(2), 5-18. https://doi.org/10.1007/BF02297309

Ibrahim, K. (2012). Fā'illiat Istrtātigiyyati taḥkkm al-muta 'llim wa tạ̣kkum al-barnāmj fì tanmiat al-tafkīr al-rriyadī wa al-ddāfi iyya lil-injāz bistakhdām al-ḥāsūb littalāmīdh bați'i al-ta'llum fì alriyādhiyyat. [The effectiveness of the two strategies for learner control and program control in developing rational thinking and motivation for achievement using computers for slow-learning pupils in mathematics]. Educational Journal, 31, 431-433.

Kingsley, K. V., \& Boone, R. (2008). Effects of multimedia software on achievement of middle school students in an American history class. Journal of Research on Technology in Education, 41(2), 203-221. https://doi.org/10.1080/15391523.2008.10782529

Ministry of Education. (2019). Ministry of Education. Retrieved from https://www.moe.gov.sa/ar/Pages/default.aspx

Mitra, S., Leat, D., Dolan, P., \& Crawley, E. (2010). The Self Organised Learning Environment (SOLE) school support pack.

Naidu, S. (1995). Definitions of instructional control in learning environments. Australasian Journal of Educational Technology, 11(1), 12-19. https://doi.org/10.14742/ajet.2065

Saudi Arabia's Vision 2030. (2017). National Transformation Program 2020. Retrieved from https://vision2030.gov.sa/en/programs/NTP

Silalahi, A., Hutabarat, W., Tarigan, S., \& Chandra, Y. (2018). Impact of multimedia-based off-line learning on student motivation and outcomes. Asian Journal of Social Science Studies, 3(4), 1-11. https://doi.org/10.20849/ajsss.v3i4.471

Thompson, N. (1995). Theory and practice in health and social care. Changing Practice in Health and Social Care. McGraw-Hill Education.

Wang, L. C. C., \& Beasley, W. (2002). Effects of learner control and hypermedia preference on cyber-students' performance in a web-based learning environment. Journal of Educational Multimedia and Hypermedia, 11(1), 71-91. https://www.learntechlib.org/primary/p/10776/

Yeh, S., \& Lehman, J. (2001). Effects of learner control and learning strategies on English as a foreign language: Learning from interactive hypermedia lessons. Journal of Educational Multimedia

and

Hypermedia,

10(2),

141-159. 
https://www.learntechlib.org/primary/p/8413/

Zard, S. (2010). Fā' illiat Istikhdām barmegiyya ta 'limiyya moqtraḥa 'ala al-taḥsīl al-dirāsī fī moqrar al-ahaiā ldā țālebāt al-saf al-al al-thānwi bimadinat Makkah Almukarrama. [The effectiveness of using an integrated educational program on students' achievement in the biology course for first-grade secondary school in Makkah Al-Mukarramah]. (Unpublished Master's dissertation). Umm Al Qura University, Saudi Arabia.

\section{Copyright Disclaimer}

Copyright for this article is retained by the author(s), with first publication rights granted to the journal.

This is an open-access article distributed under the terms and conditions of the Creative Commons Attribution license (http://creativecommons.org/licenses/by/3.0/). 